\title{
Peter Nikolaj Skougaard, Grundtvigs mathematiske ven
}

\author{
Af E. Brandt Nielsen
}

I september måned I80o kommer Nikolaj Frederik Severin Grundtvig til København for at studere theologi efter først at have taget examen artium. Her møder han en række studenterkammerater, der hver for sig fik betydning for ham, og hver for sig deres særlige skæbne. Vi kender navnene Sibbern, Molbech, Povl Dons - og ind i rækken af studiekammerater føjer sig også Grundtvigs »mathematiske ven «, bornholmeren Peter Nikolaj Skougaard, født den $3^{0}$. juni I 783, samme år som Grundtvig, på Sandemandsgaard i Knudsker sogn, søn af gårdejer og løjtnant ved Bornholms væbning Niels Pedersen Schougaard. - Peter Nikolaj var ud af en gammel bornholmsk bondeslægt og havde bornholmernes medfødte skepsis over for aristokrati og gejstlighed - man havde sjældent grund til at vente sig ret meget godt fra den kant - interesserede sig for mathematik og historie, var et barn af forrige århundredes oplysning og efter sin eksamen fra Rønne lærde skole var også han kommet til København for at studere. Skougaard er, som alle ø-boere er det, stærkt interesseret $\mathrm{i}$ sin hjemstavns historie, og udgiver allerede $\mathrm{i} 804$, kun $2 \mathrm{I}$ år gammel »Beskrivelse af Bornholm«, en bog, der vækker langt mere opmærksomhed, end man kunne have ventet. Den anmeldes sagligt, men strengt, i »Dagen « den 29. august og I. oktober ${ }^{1}$ ). Skougaard svarer godt for sig, men også denne kritik drejede sig om den usømmelige tone, de stærke angreb på levende og døde personer, især på

I. Bogen anmeldes også i »Allegemeine Geografische Ephemeriden«, Weimar I 8 I 2. Det hedder her: 》Ergüsse dieser Art verrathen ein jugendlisches überspanntes Gemüth ...«. - Bornholms daværende amtmand, Fr. Thaarup, omtaler bogen i sin »Kort Oversigt over Bornholm《 I8 10 - senere i »Bornholms Amt og Christiansø I 839. Også han anker over forfatterens usømmelige tone. På det kgl. Bibliotek findes en håndskreven recension underskrevet »Bornholms Amtmand « - skriften er ikke Thaarups, men der er måske tale om en afskrift. Det hedder her, at det nye i bogen ikke er rigtigt og det rigtige ikke nyt. Sk. har, siges det, afskrevet hele sider af de Thuras værk. 
afdøde Frederik den Tredje og hans forhold til Corfits Ulfeldt, der som bekendt havde siddet som fange på Hammershus. Bogens præg af skarphed og »den patriotiske Nidkjærhed«, hvormed den var skrevet, medfører endelig et sagsanlæg fra det offentliges side, såvel mod Skougaard som mod »Dagen «'s to redaktører, H. K. Seidelin og Albrecht Schønberg. Muligvis havde myndighederne et godt øje til bladet og fandt her en anledning til at ramme udgiverne. Anklagen rejses efter Trykkefrihedsforordningen af 27 . September I 799, der var en alvorlig trussel mod forfattere, der behandlede historiske eller politiske emner og som havde drevet P. A. Heiberg i landflygtighed. Også Grundtvig ramtes som bekendt af forordningens paragraffer efter »Kirkens Gjenmæle« i I 825. Det var altså ikke bogens historiske eller lokalpatriotiske forhold, der forårsagede anklagen, men hans omtale af øens civile og militære administration, fornærmende udtalelser om politiet $\mathrm{i}$ Rønne og de hårde ord om kongen ${ }^{2}$ ). Myndighederne ville statuere et eksempel og anklagen rejses ifølge forordningens $\S \S 2$, 3 og 4 , der alle indeholder landsforvisning for en kortere eller længere, eventuelt livsvarig periode. Regeringen var efter den korte trykkefrihedstid under Struensee følsom over for angreb - og ikke helt med urette. Generalfiskalen ser med megen alvor på sagen og er stemt for livsvarig landsforvisning ${ }^{3}$ ).

3. december 1804 indsender Skougaard et forsvarsskrift og udtaler her, at bogen er blevet til som følge af »Hypocondrie, Ungdoms-Letsindighed og Fremfusenhed « og siger, at han føler sig omgivet af »lutter udeltagende, ja fjendtlig sindede Mennesker $\left.{ }^{4}\right) \ll$.

Denne ansøgning om ophævelse af anklagen vedlægges udtalelser om bogen af professorerne Nyerup og $\mathrm{Kall}^{5}$ ). - Generalfiskalen lader

2. 1805 udgives »Forsvar for min og salig Oberslieutnant Schorr af P. N. Schougaard ubillig angrebne offentlige Agtelse« ved I. P. G. Rameier.

3. En meget udførlig fremstilling af hele retssagen findes $\mathrm{i} \gg$ Bornholmske Samlinger XXXIV, I955 ved V. Svendsen. - Se i øvrigt: A. S. Ørsted » Juridisk Archiv《 1805 , pag. 132-35, Ørsteds erindringer »Af mit Livs og min Tids Historie 《 (udgaven I95 I, pag. I 92 ) - \Collegialtidenden《 I 804, pag. 68 I.

4. Danske Kancelli, 2. Dtp., Brevbog nr. 24, 8. Januar. Ansøgningen, der ikke var juridisk udformet, var også underskrevet af Schønberg, og Skougaards bemærkninger kendes indirekte fra kancelliets svar til Schønberg.

5. Af Kalls udtalelser, fremlagt i Hof- og Stadsretten den 31. I 2. I804 (Bilag til Højesterets Dom af I I. 5. I805, pag. I03) kan anføres: »Jeg vil ganske aabenhjertet ytre min Mening om Bogen. Den røber unægtelig, at De har haft mange specielle og brugbare Efterretninger, som af hidtil utrykte Skrifter ei kan haves . Kall hævder - i modsætning til Fr. Thaarup, at Skovgaards viden er større end de Thuras. Men også Kall kritiserer bogens skarpe tone. 
sig i nogen grad formilde heraf, men kancelliet ønsker en dom af præventiv art.

Den 2. februar 1805 kommer sagen til behandling ved Hof- og Stadsretten, og det bestemmes, at der ikke kan være tale om en dom efter de strenge landsforvisningsparagraffer, derimod efter forordningens $\S 7$, der handler om den respekt forfattere af historiske værker skylder landets øvrighed. Men med hensyn til de fornærmelige udtalelser om den afdøde konge er retten i vanskeligheder, idet $\S 4$ ikke taler om afdøde, men levende konger, og de øvrige $\S \S$ nævner ikke klart det forhold. I sin tale i retten henviser assessor Dall dog til, at loven $\mathrm{i}$ alt fald indirekte sikrer også afdøde personers ære, og han henviser som parallel til Chr den Femtes lov om præsters ligtaler - »Kirkeritualets« § 9. - Dommen falder så den 4. februar 1805 og kommer til at lyde på i 4 dages fængsel, en bøde på 50 RD. for fornærmelige udtalelser om politiet i Rønne, $20 \mathrm{RD}$, i salær til generalfiskalen, konfiskation af bogen, forbud mod salg af den i bogladerne - samt ifølge $\S 20$ livsvarig censur. Kancelliet appellerer dommen til Højesteret til skærpelse, men den I I. maj stadfæstes underrettens dom. - Skougaard indsender den 20. maj en ansøgning om fritagelse for straf, men den afslås.

Dommen betragtedes også i retskredse som usædvanlig hård, men kritikkerne var, måske med Bornholms amtmand, Fr. Thaarup, som undtagelse, enige om, at forfatteren røbede store evner som videnskabsmand og megen kyndighed på det historiske område. Skougaards syn på historien var ikke romantikkens, hvor man søger idealet i den antikke verden, men derimod præget af oplysningstidens krav om objektive undersøgelser af de historiske kendsgerninger, men dommen og navnlig den livsvarige censur satte et vist præg på Skougaards fremtidige liv, selvom Steenstrup har ret i, at dette dog ikke forhindrede ham i at opnå en ret god stilling ${ }^{6}$ ). Skougaards noget tragiske skæbne bestemmes mere af indre end af ydre faktorer. I 807 forlader han København uden at have taget nogen afsluttende eksamen ${ }^{7}$ ), bliver lærer ved P. N. Frost's privatskole i Aalborg uden at have pæ-

6. Steenstrup: »Historieskrivningen i Danmark i det 19. Århundrede«, pag. I6o.

7. Grundtvig rammer centralt, når han i Mands-Minde foredraget over Skougaard siger, at »han ikke brød sig om Examen og Levebrød, men lagde sig med Liv og Siæl efter, hvad han havde Lyst til «. - K. E. Bugge har måske nogen ret, når han i sin disputats hævder, at Skougaard lærte Grundtvig at lægge mindre vægt på eksamen og levebrød. 
dagogiske interesser og anlæg, redaktør ved »Aalborg Stiftstidende«, kgl. translatør $\left.{ }^{8}\right)$, skibsmægler og portugisisk vicekonsul.

Det var tanken at Bornholms-beskrivelsen hurtigt skulle efterfølges af et nyt bind, men først I 834 kommer »Bornholms Saga «, der næppe tåler sammenligning med den første $\left.{ }^{9}\right)$. I mellemtiden er kommet en del oversættelser af mindre betydning. Skougaards forhold i Aalborgtiden synes ikke at have været så ringe. Han bliver gift den I 7. juni I 8I6 med Cathrine Marie Lehmann, og som redaktør vinder han en del venner, men nok mest fjender - hans væsen er arrogant og ironisk, og i selskabslivet spiller han i disse år en fremtrædende rolle. Han er at finde ved alle karnevalsfester og andre fornøjelser, begavet, vittig og elegant, men bag dette ydre gemmer sig en tragedie, en »problematisk karakter «, som det hedder i bladets jubilæumsskrift $\left.{ }^{10}\right)$.

Sidste gang, Skougaard ufrivilligt henledte opmærksomheden på sig, var efter hans død 1838 , hvor en del af tidens førende historikere rettede anklage mod ham for at have udspredt et forargeligt rygte om Christian den Anden, der blev beskyldt for at have stået bag ved et mordforsøg på faderen, kong Hans, der døde i Aalborg I 5 I 3 . Ved åbningen af kongens grav I $_{23}$ i Gråbrødrenes klosterkirke i Odense havde man bemærket nogle skrammer i kongens kranium, men man mente, at de kunne stamme fra en af kongens mange krige eller fra et gravrøveri, som der blev talt en del om, men aldrig er blevet fundet beviser for. I 805 åbnes graven påny, idet kongens jordiske rester nu skal flyttes over til Sct. Knuds kirke, Gråbrødrenes kirke skal nedrives, og nu konstateres ikke alene nogle skrammer, men huller i det kongelige kranium. Men heller ikke de undersøgelser, dr. Eichel foretager, giver anledning til at tro på muligheden af en forbrydelse, snarere af en sygdom. Det er ikke stedet her at behandle denne indviklede sag om kong Hans's kranium, men spørgsmålet om et eventuelt mord har spøgt $\mathrm{i}$ enkeltes bevidsthed $-\mathrm{i}$ alt fald rejses det $\mathrm{i}$ et lille læserindlæg $\mathrm{i} \gg N y t$ Aftenblad« 1827 , og der er intet $\mathrm{i}$ vejen for, at det er Skougaard, der er spørgeren, men noget bevis herfor findes næppe - det er et spørgsmål rejst til de lærde. I »Iversens fyenske Avis« kommer kort tid efter et svar, hvor teorien afvises og hvor der henvises til en indberetning til kancelliet af »salig Biskop Hansen« $\mathbf{i}$

8. Hvelplund: 》Kgl. Danske Translatører i 782-1 $848 \ll$.

9. Chr. Stub-Jørgensen: »Peter Nikolaj Skovgaard og hans bøger om Bornholm, Rønne 1958 《.

I o. »Aalborg Stiftsbogtrykkerie« I 943 ved Em. Sejr. 
Odense. Svaret kan være givet af historikeren C. Paludan Müller, der var adjunkt i Odense, i alt fald er det ham, der 1843 i »For Literatur og Kritik«, I. bind, udgivet af Fyens literære Selskab, lader offentliggøre et foredrag herom ${ }^{11}$ ). Paludan-Müller skriver, at han havde troet, den gamle historie forlængst var glemt, men beretter nu om et mærkeligt fund, man i sommeren 1837 , året før Skougaards død, skal have gjort på Nytorv i Aalborg og som bestod af en blykapsel med en læderrem - et skindbrev - hvorpå der skal have stået, at kong Hans blev myrdet af et par navngivne personer på hertug Christians foranledning. Skougaard skal have været til stede ved dette fund og have skrevet en redegørelse for det med en tydning af indskriften på skindbrevet. - Paludan-Müller gengiver meget detailleret alle disse ting, undersøger skindbrevets alder og indskriften, som han iøvrigt mener, at Skougaard tyder forkert, gengiver dennes redegørelse og retter et skarpt angreb mod den 1838 afdøde litterat, fordi han ved ikke at tilintetgøre sin anmeldelse eller dementere den offentligt, har været med til at udbrede et skændigt rygte om Christian den Anden. Det besynderlige og helt urimelige i denne sag er, at Skougaard aldrig har offentliggjort sin anmeldelse, der lå i hans skrivebord og blev fundet efter hans død. Paludan-Müller er i vildrede med sagen, han er klar over, at der er tale om et bedrag, men hvem der bedrager hvem, kan han ikke se, og hans beskyldning mod Skougaard er grundløs og kan kun forklares ved, at han havde tiden omkring Christian den Anden som speciale og følte sig som dennes defensor - og at der var stærke kræfter igang, især i Skougaards fraskilte hustrus familie, på at sværte ham til mest muligt.

Mens Paludan-Müller ikke tør sige, at Skougaard har forfattet indskriften selv eller lavet et bedrag, går såvel C. F. Allen som C. H. R. Steenstrup et skridt videre, idet begge uden betænkning kalder Skougaard en historisk svindler, og bornholmeren, lægen og historikeren Zarthmann går endda så langt, at han kalder Skougaards »anmeldelse (der altså aldrig i hans levende live nåede længere end til skrivebordsskuffen) for »det mest æreløse Falskneri, dansk Historieskriv-

I I. Paludan-Müller henviser til Behrmann: 》Christian den Anden《 og til Werlauff: »Monument over Kong Hans« I 827. - Øvrige kilder er Huitfelds »Kong Hansis Krønike《 1652 og Fohan Svanings »Refutatio caluminarum cujusdem Ioannis Magni«, 156o. - Om emnet se i øvrigt Henrik Møller i »Medicinsk Forum « I 5. årg. nr. 5, I962, A. Lübbers i »Ugeskrift for Læger《 I 90 I samt Palle Lauring: »Danmarks håb og horn《. Teorien om et mord på kong Hans skal være fremsat første gang af Martin Arendt fra Altona. 
ning kan opvise«. Skougaard havde ifølge sin landsmand ikke alene selv forfattet indskriften, arrangeret fundet, men også påstået, at kong Hans blev myrdet ved gift! - hvor han så har det $\mathrm{fra}^{\mathbf{1 2}}$ ).

Den rette løsning på gåden omkring Skougaards andel $\mathrm{i}$ fundet kan næppe gives, men to ting må stå fast: Skougaard var ikke i sine Aalborg-år et falleret menneske. Hans sidste bog: »Haandbog for Handels-Correspondents « fra I 835 viser ikke et menneske i opløsning. Det er et banebrydende værk af sin art, foreløbig det første i dansk litteratur om det emne, og af subskriptionslisten fremgår, at han har haft et nogenlunde kendt og agtet navn ud over Danmark, hvilket også indirekte kan ses af den iver, hvormed tidens og eftertidens historikere søgte at reducere hans betydning. Den ville have været ganske overflødig, om han kun var et vrag, en historieforfalskner og svindler. Og dernæst: han har selv intet offentliggjort i denne sag, sålidt som han har indsendt fundets genstande til oldsagskommissionen. Det gjorde boghandler Lundt efter hans død.

Ved hans død skriver biskoppen i Aalborg, Fogtmann: Skribenten, Konsul P. N. Skougaard er død. Han døde i Usselhed i alle Maader. Han havde iøvrigt et klart Hovede og gode Kundskaber og det begge Dele i virkelig fortrinlig Grad. Nu er han saa svækket af Drik, at han hver Dag maatte have i det Mindste 1/2 Pot Brændevin. Han vedblev at arbejde med literære Arbejder til det sidste ${ }^{13}$ ) $\ll$. Bemærkningen til slut modsiger jo i grunden brevets øvrige karakteristik af Skougaard som et fordrukkent vrag. - Ved hans død bringer »Aalborg Stiftstidende« en nekrolog, der på visse områder skyder over målet, mens den på andre punkter rammer plet: »Den nysafdøde Literatus Peter N. Skougaard var i flere Henseende en mærkværdig (bemærkelsesværdig) Personlighed. Han besad en stuvend Masse Kundskaber og hans Hoved var en levende Lexicon i alle nye og gamle Sprog. Derhos besad han en bidende Vittighed, og Faa have vel havt en saadan Styrke i Ironien som han. Hans Styl var eiendommelig, men

12. Allen: $\gg$ De tre nordiske Rigers Historie ${ }_{1} 865$, pag. 521 , note 7. Steenstrup: »Historieskrivningen i Danmark i det 19. Aarhundrede《 pag. I6I. - Samme i »Dansk Biografisk Leksikon« 1902, bind XVI, pag. 76. - M. K. Zarthmann: »Til Belysning af Bornholmernes Opstand mod de Svenske r658. De danske Kilder«. (»Historisk Tidsskrift«, 6. række, 5. bind, I 894-95, pag. 236 ff.).

1 3. Fr. Nielsen: »Grundtvigs religiøse Udvikling« I 889, pag. 34. Det eksemplar af »Beskrivelse af Bornholm《 som findes på Statsbibliotheket i Århus, har tilhørt Laurids Engelstoft. Denne skriver foran i bogen: $\gg$ Denne Bog blev i sin Tid confiskeret. Forfat. død som Translateur i Aalborg 1838. Han var til sidst noget forfalden og døde i ussel Forfatning «. 
kraftig og reen. Med alt dette forfejlede han dog sin Bestemmelse paa en sørgelig Maade, og de udvortes Kaar hvori han levede, dannede en skærende Modsætning til de glimrende Evner, hvormed hans Aand var udstyret. Han var de censurdømtes Senior i Danmark. I en mesterlig Beskrivelse over Bornholm, hans Fædrenenø, havde han forsyndet sig mod Forordningen af 27. September I 799. Siden skrev han Intet af Betydning, og var saaledes et levende Vidne om, hvorlunde livsvarig Censur lammer de dygtigste Kræfter. Skougaard var aandeligt som legemligt, en sand Kæmpenatur, men, skiønt hans Aand, gjennem alle Stadier af et synkende Liv, bevarede sin Kraft, maatte dog hans psykiske Natur bukke under for de Angreb, der med hver Dag fornyedes. Ved sit udvortes Liv minder Skougaard om Evald og $\left.\mathrm{Wessel}^{14}\right) \ll$.

\section{II}

Det første møde mellem Skougaard og Grundtvig har nok fundet sted sommeren I8o I, da de begge som medlemmer af studenterkorpset var til mønstring på Fælleden ${ }^{15}$ ). De var født samme år, og efter Grundtvigs eget udsagn så forskellige som mennesker kan være. Men på to områder kunne de mødes: i deres kærlighed til historien, trods deres vidt forskellige opfattelse af, hvad historie var, og i det dramatiske theater. - I den interesse mødte han i øvrigt samtidig en anden bornholmer, Jacob Steenberg, der senere blev præst ved Århus. Han havde stiftet amatørklubben »Thalia«, og her opførte man Heibergs »Virtuosen. Nr. 2«, hvor både Skougaard og Grundtvig spillede med, og Heiberg har nok påvirket Grundtvigs »Skoleholderne«, som blev skrevet 1802 - renskrevet af Skougaard og indsendt til Det kgl. Theater, men returneret ${ }^{16}$ ). - Grundtvig har selv givet flere skildringer af dette sit møde med Skougaard. I dagbogen - den omarbejdede

14. Se Øst's Materialier nr. I47, I 838 .

15. Se Rønning I, I pag. 32 ff. - Endvidere Ludv. Schrøder: »Grundtvigs Barndom og tidlige Ungdom《 I883. - I Ill. Dansk Litteraturhistorie giver Vilh. Andersen en karakteristisk beskrivelse af mødet mellem Grundtvig og Skougaard: »Men i Korpset lærte han (Gr.) P. N. Skougaard at kende, som med sit stridige Sind, han var Bornholmer af Fødsel, og sin kraftige Smag, han læste Sagaer paa Oldtidssproget, gav hans Danskhed det førstehaands Indtryk, hvortil den trængte $\ll$. (III, pag. I 44).

16. Om Grundtvig og theateret se bl. a. Neiiendam: »Gennem mange Aar« og Steen Johansens indlæg i Gr.-studier. Afskriften af »Skoleholderne«, ved Skougaard, findes mellem Grundtvigs papirer. Afskriften er sprogligt ikke tilfredsstillende, se herom: »Acta Philologica Scandinavica XIX I46« af Toldberg. 
- fra I 802 skriver han: »Under dette Ophold i Hovedstaden lagdes ellers Grunden til et Bekjendtskab, som han stedse siden har med Fornøielse vedligeholdt, med en bornholmsk Student cui nomen Peter Nikolai Skougaard. At dette Bekjendtskab ei, som saa mange andre, opkom og forsvandt, dertil laae fra først af Grunden i, at Grundtvig yndede Nordens Historie, og derfor var saare glad ved at træffe En af de Faa, der baade yndede og kjendte den«. - I et utrykt manuskript »Om mit Forhold til det antiqvariske Studium ${ }^{17}$ ), som er et forarbejde til en afhandling til Dannevirke: »Et Par Ord om Oldgranskning «, skrevet juli-august $\mathrm{I} 8 \mathrm{I} 7$, omtaler han påny mødet: »Hvad der udvortes reddede mig, var, som jeg før har sagt, og aldrig kan glemme, det, efter Talebrugen tilfældige, Bekiendtskab, der i Anledning af Studenter-Væbningen timedes mig med Bornholmeren P. N. Skougaard, en Mand der syndes skabt til de største Polyhistorers lykkelige Medbeiler«. - Videre i dette manuskript, som Grundtvig aldrig lod offentliggøre, fordi han vel har anset dets omtale af Skougaard for at være for personlig, hedder det om følgerne af dette møde: »Ingenlunde lærde dette Bekiendtskab mig at forbinde min academiske Bane med min videnskabelige Drift, det bestyrkede mig snarere i den Troe, at derimellem var et unedbrydeligt Skillerum, og hvad havde heller i Grunden hine Dages Theologie med Historien at giøre! men jeg fik dog et Menneske, med hvem jeg kunne tale om hvad jeg elskede, uden at besvares med Latter eller Skuldertræk, jeg fandt en Jævnaldrende, som var langt forud for mig i Kundskaber, som alt var en gammel Ven af Edda, Saxo og Snorro, som læste Islandsk og Runer, som kunde sig mig hvor der var Noget at hente, som førde mig op paa Runde-Taarn for Andet end at gabe ${ }^{18}$ ), kort sagt en virkelig Privat-Præceptor . . .««

Ved budskabet om Skougaards død mindes Grundtvig ham i Mands-Minde-foredraget den 26. september 1838 , og her omtales hint møde ligeså: »Et Lykketræf maa jeg derfor kalde det, at min Kjærlighed til Nordens Historie paa denne Tid atter vaagnede, og mit egentlige Bekjendtskab med det gamle Nordens Guder og Helte stiftedes; thi dertil gav Kampen paa Kongedybet kun Anledning, da

I 7. Se Helge Toldberg i Grundtvig-studier 1955, pag. 55 ff: »Et uænset, egenhændigt vidnesbyrd om Grundtvigs ungdom《. Toldberg har fundet ms., kommenteret og dateret det med megen sikkerhed.

I8. I et privatbrev erkender Toldberg, at hans tese: Skougaard har indviet Grundtvig i astronomiens mysterier, er forkert. Den arnemagnæanske samling fandtes på loftet over Trinitatis kirke med indgang gennem Rundetårn. 
jeg i Studenterkorpset stødte paa en jævnaldrende Bornholmer, den siden saa ulykkelige, nylig i den dybeste Elendighed afdøde $P$. N. Skougaard; thi ved Siden af ham var det ikke, som i Aarhus Skole, for min Styrke, men for min Vankundighed i Historien, jeg maatte skamme mig. Saxe og Snorre, Eddaerne og hele Islands Sagarække, som jeg kun kjendte af Navn, var nemlig en Kundskabs-Kreds, hvori han bevægede sig saa frit og let som i sin Hjemstavn; og skjønt han var intet mindre end poetisk stemt (d. v. s. slet ikke poetisk), var Matematiker med Liv og Sjæl, laa dog hele Verdenshistorien ham saa nær og syntes saaledes indtaget af ham, som en Napoleon i Bogverdenen, at saaledes havde jeg aldrig beundret noget Menneske; og hans Bekiendtskab maa jeg da ikke blot takke for mit forholdsvis tidlige Bekjendtskab med Nordens Oldtid, men i det hele for den levende Følelse: at uden for hele Examens-Kredsen laa der en Verden af Kundskaber, det godt lønnede Umagen at berejse. Derved var jeg reddet fra den Dovenskabs og Kjedsommeligheds Afgrund, hvori Skolefuxeri og Examens-Slendrian paa et hængende Haar havde styrtet mig; og har eller faar mit Liv nogen videnskabelig Betydning, da var det (bekendtskabet med Skougaard) aabenbar (ganske klart) Betingelsen, men dog hverken Kraftgrunden eller Livskilden; thi det er kun Aanden, og om Aand havde min bornholmske Ven lige saa lidt som jeg mindste Begreb, naar Aand skulde være andet end paa den ene Side vor gode Fornuft og Forstand og paa den anden spillende Vittighed «. - Det er om denne omtale af Skougaard, Hal Hoch i indledningen til »Værker i Udvalg«, I. pag. XIV-XV siger, at den »rammer lige i centrum«. (Cit. efter »Grundtvigs Erindringer . ..« ved Steen Johansen og Henning Høirup).

Men endnu et sidste vidnesbyrd om betydningen af mødet med Skougaard finder vi i erindringsbogen $\gg$ Kirke-Spejl«, skrevet I 86 I-63, hvor vurderingen af vennen fra de unge år har samme klang som i de første dagbogsoptegnelser: »Jeg var imidlertid fra ganske andre Kanter vaagnet lidt af Skoledøsen, dels ved den stærke Kanonade i Kongedybet, hvormed Helten fra Abukir (Nelson) skød Folkelighedens Aarhundrede ind, og dels ved Nordens Oldkrønnikker, som en Krigskammerat, Bornholmeren Skougaard, stak mig i Næsen, og endelig ved den forskrækkelige Støj, min halvtyske Fætter, Henrik Steffens, gjorde paa Ehlers Kollegium, saa Regensen nær var falden ned ... - Som Grundtvig andetsteds har omtalt Skougaard i forbindelse med såvel Schiønning, Nyerup som Gräter, nævnes han her sammen med 
Steffens, hvis forelæsninger Grundtvig aldrig glemte, og oplevelsen af det engelske bombardement, en sammenstilling, der også findes i selvbiografien i 84 I til Erslews leksikon.

Det er værd at lægge mærke til, at Grundtvigs bedømmelse af Skougaard er den samme fra dagbogens første blade til alderdomsskriftet »Kirke-Spejl《: - han beundrer vennen for hans viden, overmenneskelige flid, forskertrang og udholdenhed og hans trofasthed $i$ venskabet under de mange skiftende kriser i sit liv. Når man betænker, hvor svingende Grundtvig ellers var i sin bedømmelse af andre mennesker, er dette et stærkt vidnesbyrd om Skougaards overmåde store betydning.

Men inden vi ser lidt på dagbogens vidnesbyrd, vil vi standse ved de to ungdomsdigte, der findes mellem Grundtvigs papirer, begge skrevet til Skougaards fødselsdag - og ved brevene, hvoraf kun en del er trykt, og hvor vi desværre helt mangler den korrespondance, dagbøgerne omtaler og som må have været særdeles omfattende.

Af ungdomsdigte til Skougaard kender vi foruden udkastene til »Strandbakken ved Egeløkke« (som vi omtaler nærmere i en senere sammenhæng) to hilsener til fødselsdagene 1802-1803. Det første står i en stilebog fra Århus-tiden og er til Skougaards 19 års dag - ikke som opgivet af Ronning hans 20., for når man går ind i sit tyvende år, bliver man nitten! Manuskriptet er vanskeligt at tyde med sine mange rettelser og uforståelige ord, men et indtryk af Grundtvigs følelser fås vel af dette uddrag:

Elsket af Venner og yndet af Muser

Træder Du ind i det tyvende Aar

Ynglingens Ild i hver Aare nu bruser

$\mathrm{Nu}$ er Du midt i Ungdommelig Vaar.

Dag Du som Schougaar (d) til Lyset frembragte

Hilset Du være af glødende (?) Ven

O! tør jeg bede (,) dig (?) langsomt og sagte

Seent paa sin Bane din Sol glide hen.

Giv mig Euterpe hin yndede Muse

Du hvem han dyrker med utrættet Fliid

Stig fra de Grotter som ellers dig huse

Løn med dit Bifald hans værdige Iid.

Dog som en Christen det bør mig at iile

Bort fra hver Hedning og Belials Søn

Lad dem kun længe nok (fuldelig?) hviile

$\mathrm{Nu}$ kun til (Christne?) jeg vender min Bøn. 
Du som den Norske Historie skabte

Du som den atter af Glemsel tog op

Om I end alle Beundrere tabte

Hin Jer dog hæver til Hæderens Top.

Digtet er præget af den varme hvormed Grundtvig omfatter sin ven, hans hjertelige hyldest, og derefter af en vis humor: han burde som kristen vende sig fra »hver Hedning og Belials Søn« og kun vende sin bøn til de kristne, men forbindelsen med Skougaard er så værdifuld, at han her gør en undtagelse. Endelig er det historikeren Skougaard han hilser - og sætter ham ind i sammenhængen med såvel Schiønning som Snorre, en hæderfuld plads:

Schougaard! en Schiønning, en Snorro du ligne

Nedgrav ei Pundet der faldt i din Lod

Da skal hver Nordbo dit Minde velsigne

Tree talte værdig om Nordmandens Daad.

Og som det fasteste Vennebaand knytter

Lad os paa Banen gaa samlede frem

Indtil gid sildig vi begge bortflytter

Over fra Jorden til Sielenes Hiem ${ }^{19}$ ).

Resten er ulæselig og uforståeligt. - Og til fødselsdagen det følgende år 1803, og nu er det hans tyvende, skriver Grundtvig igen et digt:

Til N. P. Skougaard paa hans Fødselsdag d. $30^{\text {te }}$ Juni 1803.

Gid snart Du faae en yndig Kone

Gid Du som Krøsus vorde riig

Det jeg dig ønsker uden Sviig:

Saa lød den gamle Ønsketone.

Men man er saare ilde tjent

Med Tønder Guld paa Skrift og Prent

Da derved ei en Skilling kommer (?)

I vore Lommer.

Desuden bandsat Lyst jeg har

Til at agere Orignal

Thi er man da endog en Nar

Er man dog ei paa andre gal.

19. Fasc. 488,2 - delvis citeret hos Michelsen i »Tilblivelsen af Grundtvigs historiesyn $\ll$ pag. 196. 
Jeg derfor ønsker tvertimod

Gid Lykken ei dig vorde god

Gid hun dig stedse Ryggen vende

Men gid du stedse have Mod

At vise hende samme Ende.

Sliig Lærdom udi vore Tider

Langt meer end røde Guld er værd

Jeg ikke længer rime gider

Thi lange Kvæde ilde klæ'r

Jeg siger blot Jeg er hans Ven

Adiø min Herre! og min Pen!20)

Hvad brevene angår er altså hele den omfattende korrespondance, som omtales i dagbøgerne, borte, og fra Grundtvigs hånd kender vi kun eet, der tilmed mangler udskrift, men indre kriterier afgør, at det må være til Skougaard, og det findes kun som udkast eller kopi - ingen kan afgøre, om det nogen sinde er kommet Skougaard i hænde. Det er dateret den 4. juni i8o8, hvor Skougaard er lærer ved Frosts's skole i Aalborg, Grundtvig alumne på Valkendorfs kollegium i København. (Se »Breve til og fra N. F. S. Grundtvig « ved Stener Gr. og Georg Christensen, I, nr. 7.) - Grundtvig harcellerer over, at han længe intet har hørt fra sin ven, ved ikke om han har begivet sig til sine fædre »- dog - en vis Mand frier nok sine«, og videre fortæller han om sit arbejde med den gamle Edda, NibelungenLied og Maskeradeballet, som han arbejder med. Brevet viser deres fælles interesse: historien og det dramatiske theater, og er præget af en munter, studentikos tone. Utrykt, mellem Grundtvigs papirer, finder vi et brev fra Skougaard - dateret den 27. august I8I I, og af det skal anføres lidt udførligere:

Gode Ven!

I den Forhaabning, at Du dog tilgiver mig min lange Tavshed, er det at jeg idag herved paa ny begynder den i saa lang Tid uforsvarligen afbrudte Brevveksling. Tro ikke, at jeg kunde være i Stand til at glemme det Venskabsforhold, hvori vi tilforn - i Rosengaarden og andre Steder - stode til hinanden. Nej, ofte har jeg gennem Skilderiet etc. havt Underretning om Din Tilværelse og bestandige Fremgang paa Banen, som Du bestemtes at vandre paa. - For at tilfredsstille en af de Fordringer Du har til mig, nemlig at vide hvorledes jeg

20. Fasc. 489 a 5. - For hjælp ved tydningen af Grundtvigs manuskript bringes dr. theol. Kaj Thaning en hjertelig tak. 
har det her, maa jeg underrette Dig, at det meste jeg herom kan sige, er at jeg slider Tiden og slides af Tiden.

Han beretter nu, at Frost's skole er nedlagt, og han for tiden kun beskæftiger sig meget lidt med undervisningsfaget - kun enkelte privattimer bliver det til. »Mit egentlige Hverv er nu at bringe endel ensformigt Rageri af Handels- og Skibspapirer, samt Retsforhandlinger over fra et til et andet Lands Sprog, som jeg er berettiget til at gøre nu, efterat Kongen sidst i afvigte Aar gjorde mig til Tolk og Translatør i Engelsk, Fransk, Hollandsk, Tysk og Svensk, for Aalborg Stad og Stift«. Han karakteriserer embedet som undertiden ret givtigt, men dog i det hele ret usikkert. Dernæst oplyser brevet, at han i nogen tid har besørget »den politiske Artikkel « $\mathrm{i}$ et af Aalborgs blade, og det giver ham anledning til uden bekostning at læse en række blade og tidsskrifter, især har han haft megen glæde af at læse Skilderiet: »Der findes tidt Smaastykker deri, som fortjene at læses, og især har det glædet mig, at finde et og andet af Dig«. Men han er fremmed over for al anden litteratur, og skal han blive bestandig her i det »blot mercantile Aalborg, hvortil i den senere Tid kommer yderst faa Danske Bøger, og aldeles ingen fremmede«, så frygter han for at gå åndeligt til grunde, og det gamle studium har han helt foraldt, da der ikke er hjælpemidler at få i byen. »Bedre gaar det med min Mathesis, « hedder det, »forsaavidt den er apriorisk, for Math. applicata (matematiske sysler) er ikke at tænke paa her.« - Derimod har han beskæftiget sig med »de fremmede Sprogs Grammatikker og Lexica, som jeg skal leve af.«

Det næste brev - trykt i Breve I, nr. 50 - er fra I4. april I 8 I 2 og er bemærkelsesværdigt ved den forståelse, Skougaard lægger for dagen med hensyn til Grundtvigs kristne gennembrud og arbejde som præst i Udby sogn. Skougaard var ikke videre kirkelig, vel nærmest et barn af det forrige århundredes rationalisme i filosofisk og theologisk forstand, men han udtrykker dog en varmtfølt glæde over, at Grundtvig er vendt tilbage til sit barndomssogn som præst. Han betegner den forandring, der er sket med Grundtvig som betydelig, men er betænkelig ved at vide ham så langt borte fra Københavns bibliotheker og den arnemagnæanske samling, ønsker til lykke med Grundtvigs forlovelse med Lise Blicher. Skougaard glæder sig oprigtigt over, at det går fremad for vennen »i den theoretiske som praktiske Kristendom. «Han er lige så oprigtigt bange for, at de fleste præster kun prædiker evangeliet for de fede tienders skyld. Han 
højagter enhver præst, der ikke blot har Kristi evangelium i munden, men også i hjertet, men hader øjenskalkene, der ikke mener, hvad de siger, »og dette er Aarsagen til at jeg næsten aldrig gaaer i Kirke, da jeg ingen Opbyggelse finder der.«

Men det vigtigste af de kendte breve er vel et fra Grundtvig den 21. november I8I5, hvor han beder sin gamle ven om hjælp ved oversættelsen af Saxe og Snorre. Brevet kendes indirekte af Skougaards svar den 4. december samme år, og svaret bliver et nej. Han vurderer såvel Grundtvig som det videnskabelige arbejde så højt, at han ikke vil være med til noget, som han ikke kan gøre samvittighedsfuldt nok. Skougaards afslag er dikteret af hans respekt for det videnskabelige arbejde. - Dog er hans svar ikke helt afvisende - han beder Grundtvig skaffe sig den københavnske udgave af Snorre og den danske oversættelse af Saxe, så skal han gøre, hvad han kan, men »meget kan du just ikke vente af mig, men tag Viljen i Gjerningens Sted og vær nøjsom! - Med et par ikke særlig opmuntrende ord om sig selv slutter brevet: »Hvad mig selv angaar, da hugger jeg mig igjennem, som jeg bedst kan, og har i disse Tider nok at bestille med at erhverve saa meget, som jeg behøver for at leve anstændigen.«

Det sidste brev, vi kender, er utrykt, dateret den 7. juni i 8 I6, og det synes at røbe en vis afstand eller forretningsmæssig kølighed. Måske er det blot Skougaards brevstil, der er blevet mere formel end den har været?

\section{Kjære Ven!}

Dit meget behagelige Brev af April 29. har jeg med Glæde modtaget den 4. i samme Maaned og burde da uafladigen have besvaret samme ... H Han fortæller at han just er blevet gift og skriver videre, at han ikke kan finde bladet med Grundtvigs subskriptions-indbydelse, men den var underskrevet og anbefalet af »Hrr. S. J. Molkte, Jansen og Zauber $\left.\ll^{21}\right)$. Det er stiftamtmanden, biskoppen og rektor ved kathedralskolen. S. J. betyder Societas Jesu, en ironisk betegnelse for stiftsøvrigheden. - »For din Ulejlighed med at skaffe mig en Snorre er jeg forbunden, og begynder allerede at længes efter igjen at faae Snorre paa Islandsk at læse i, som nu har været mig forment i næsten

2 I. I et brev til G. Molbech skriver Skougaard den I5. november i 8 I6 i anledning af M.'s bøn om hjælp til at tegne subskribenter til en bog: »Megen Læselyst findes ikke i Aalborg Stad eller Stift. ... Paa Grundtvigs Oversættelse af Edda fik jeg $7 . \ldots \ll$. 
en halvt Snes $\mathrm{Aar}^{22}{ }^{2}$. - Skougaard omtaler dernæst Grundtvigs »Angelsachiske Arbejde«, oversættelserne af Beowulf fra Thorkelins udgave: »De Danorum Rebus Gestis Secul. III og IV Poëma Danicum Dialecto Anglosaxonica «. Det hedder her: »Jeg vilde ønske, jeg havde mere Lejlighed til selv at offre disse Sprogs Dyrkning mine Fritimer, men derpaa er nu i Aalborg vel ikke at tænke. Blot jeg endda engang imellem, af og til, kunde finde Lejlighed til at gjøre en Excursion herfra til Kjøbenhavn, som al Dansk Videnskabeligheds Middelpunkt; men heller ikke dette vil min Tid tillade mig«. - At brevet dog ikke er ment som et afskedsbrev, hvad det blev, siges i slutningen, hvor Skougaard beder om at få nogle »literære Nyheder«, når han igen får brev fra Grundtvig. »Af Blade har jeg Dagen, som just ikke er synderlig underholdende her, og Adrastea $^{23}$ ), som med al dens Kjevlen med Baggesen dog lader sig læse, samt Kjøbenhavns Skilderie, Statstidende og Literaturtidenen, Collegialtidenden etc. men alle disse er mig ingenlunde fyldestgjørende.

Til kjærlig Erindring anbefaler sig Din trofaste Ven. P. N. Skougaard.

\section{III}

For ret at forstå den betydning, den unge Skougaard havde for sin ven og studiefælle, er det dagbøgerne, vi skal se på. Her skal dog kun hovedtrækkene i Grundtvigs dagbogsoptegnelser nævnes ${ }^{24}$ ).

Optegnelserne fra I8o I-02, den såkaldt omarbejdede dagbog, der rettelig er et forsøg på en selvbiografi mere end en dagbog, fortæller, hvordan Grundtvig I 8o I ligesom så mange andre studenter greb til våben, og at han efter overstået filosofikum april i 8 o I rejser hjem til Udby. Her finder han Suhms Danmarkshistorie med et hidtil ubenyttet stof, og han stifter også denne vinter bekendtskab med Samsøe, hvis dramatiske værk »Dyveke« han nu læser, idet en god ven låner ham bogen. Det er iøvrigt i dagbogen for 1804 - den originale - at vi kan finde Grundtvigs syn på den historiske fortælling, der i denne tid

22. Den københavnske Snorre er Schiønnings, som Grundtvig på en auktion i april i 8 6 købte, formentlig til Skougaard.

23. - et Oppositionsblad (Litteraturen, Politiet og Theatret helliget) ved Chr. Steen. - Kbhv. I 8 I5-1 7 .

24. Gustav Albeck: »Grundtvigs vej til de norrøne skrifter « i Gr.-studier r 953. Helge Toldberg: »Grundtvig som filolog«. - Niels Kofoed: »Grundtvig som selvbiograf $\ll$. 
endnu er hans ideal. Han vil skrive slige romaner efter Suhms mønster, men også de gamle islandske sagaer er hans forbillede, ligesom han omtaler Voltaires fortællinger om Karl den Tolvte som idealet. Han anlægger ikke oplysningstidens syn på historien, men derimod det æstetiske: den opdigtede fortælling beretter kun om fingerede tildragelser, men den historiske roman om virkelige ting og hændelser; selvom læseren af den historiske fortælling er blandt ukendte mennesker, er han dog »mellem Mennesker, mellem sine Brødre«, fordi det trods alt er historien, der ligger til grund for romanen, hvor meget forfatteren end har taget sig frihed til at forme sin historiske fortælling efter sit eget hovede. Det er forholdet til virkeligheden, der er det væsentligste for Grundtvig i denne tid. Den historiske roman er hverken digt eller historie, men begge dele, hvilket han ikke anser for en mangel, men for en fordel, ja en fuldkommenhed - bare den ting, at den historiske fortælling har sandsynligheden i sig, gør den anderledes, i forhold til den rent opdigtede roman. Så sikker er Grundtvig på denne metode, at han nok vil tage imod vink til forbedringer, men ikke på nogen måde holde op, >så længe jeg føler Kraft, saa længe Afsætningen, eller jeg selv, kan betale Bogtrykkeren«.

Skougaards rolle i denne tid er klar nok. Han reviderer vennens historiske oplysninger og søger at få ham til at læse sagaerne på Islandsk, men indtil videre uden held. Grundtvig er så sikker, at det helt preller af på ham, når Skougaard i sine breve retter indvendinger mod dette forfatterskab. Brevene fra Skougaard, som vi kun kender indirekte gennem Grundtvigs referat, viser, at hans »mathematiske Ven« er fortrolig med den arnemagnæanske samling, de enkelte håndskrifters afvigelser $\left.\mathrm{og} \operatorname{sprog}^{25}\right) . \mathrm{Og}$ brevekslingen synes at have været omfattende $i$ dette år. Utålmodigt har han ventet på et svar fra vennen angående »Ulfhild «: »Vel er jeg intet Fruentimmer, men dog længes Jeg efter at see dem (nyhederne), især ønskede Jeg at høre lidt om min Datter Ulfhilds Skjebne«. Således skriver han den 29. maj I804, og dagen efter afgår igen et brev til Skougaard. Grundtvigs kendskab til den norrøne litteratur er endnu meget ringe. Den 28. februar I804 har han noteret sig titelen på Sandvigs oversættelse af Sæmunds Edda, og i selvbiografien til Erslews leksikon hed-

25. Når Toldberg (anf. værk pag. 46) siger, ganske vist som en rekonstruktion, at heller ikke Skougaard havde noget indgående kendskab til de norrøne skrifter, er det givet en forkert rekonstruktion. Brevene og dagbøgerne synes at vise det modsatte. Toldberg har her alene holdt sig til Rønning. 
der det, at det var Skougaard, som henledte hans opmærksomhed på dette betydningsfulde værk til forståelse af de gamle skrifter ${ }^{26}$ ).

Forholdet mellem de to venner er karakteristisk på den ene side ved Skougaards energiske forsøg på at få Grundtvig til at lære Islandsk og tilegne sig en videnskabelig metodik, det vil sige opgive sit æstetiske syn på det historiske materiale - og på den anden Grundtvigs stædige vægring ved at forlade sin engang indtagne position.

Det islandske sprog står og spærrer ham vejen som »en fjendtlig Genius«, men ved Finn Jonssons hjælp når han at beherske sproget. Foreløbig kommer der dog andre ting i vejen. I805 er ellers et afgørende år. En krise er undervejs, og den udfolder sig også i hans forhold til historien ${ }^{27}$ ). Studiet af det islandske sprog har vist ham, hvilket overvældende stof, han står over for. Dertil kommer, at hans plan om en doktorafhandling om Knud den Store opgives, og i hans syn på historien er der ved at ske en ændring, der varsler den romantiske periode. Han havde nu tilegnet sig Skougaards videnskabelige, metodiske syn, men svinger langsomt over fra den kritiske forskning og de sproglige studier til at fordybe sig i de norrøne skrifters åndelige indhold. Men foreløbig er året i 805 præget af, at han skal flytte til Egeløkke, uden at han endnu aner, hvad det skal komme til at betyde for hans liv, og han skal indrette sig der. Med sig til Egeløkke medbringer han en række bøger, som han senere har skrevet en fortegnelse over: »Optegnelser paa de Bøger jeg ejer og ejende vorder begyndt den XXde Decbr. MDCGGV Nikolaj Frederik Severin Grundtvig Ludimagister Egeløkke $\left.\ll^{28}\right)$. - I afhandlingen »Et Par Ord om Oldgranskning « i Dannevirke hedder det: »Ledsaget af Sandvigs Edda, Anders Vedels Saxo, Peder Clausens Snorro, nogle Sagaer, Olavsens Bog om Nordens Skjaldskab, Arild Hvitfelds Krønike, de tre første Bind af Suhms danske Historie, med hvad andet dansk histo-

26. »Han (Grundtvig) tog første Examen (180o) og Theologisk Attestats (1803) i Kiøbenhavn, men kunne ikke udholde at høre nogen Forelæsning (betyder forelæsningsrække) til Ende, undtagen sin Fætter H. Steffens' om Gøthes Digte, og blev kun ved Bornholmeren P.N.Skougaard bekiendt med Vedels Saxo, Clausens Snorro og Sandvigs Edda og den virkelige Tilværelse af en Islandsk Bogskat fra Middelalderen «.

27. Uafhængigt af hinanden mener Albeck og Toldberg, at der forud for den kristelige krise I 8 I 0-I I ligger en »kontemplativ « krise. Se Toldberg: (Grundtvigs symbolverden« pag. I 2 og samme i »Acta Philologica Scandinavica« XIX, 1950, pag. I64. Gustav Albeck: 》Strandbakken ved Egeløkke« - i Gr.-studier 1954 .

28. Denne bogfortegnelse er fyldigere end fortegnelsen i Dannevirke-afhandlingen, den nævner også Skougaards »Beskrivelse over Bornholm《. 
risk jeg havde sammenplukket, og med den Smule Islandsk, jeg, uden Veiledning, havde stavet mig til; med dette Huusgeraad, som jeg fornemmelig havde min venlige Staldbroder, den tidlig lærde og tidlig fra Bogen forsatte, P. N. Skougaard, at takke (for), begav jeg mig, som mig syndes, i Landflygtighed som Skolemester, og her, i landlig Eensomhed, uden Forbindelse med Nogen, der kiendte eller elskede Nordens Oldtid, giærede det i mig, til Sponsen af sig selv fløi op, og jeg blev Forfatter ${ }^{29}$ ).

Men året 1805 gik til enden uden af »Sponsen af sig selv fløi op« - ved årets slutning gør han status igen, og undrer sig over, at han intet skriver, han har ellers før både skrevet og rimet, arbejdet med sin gamle kæphest, den historiske fortælling, men det hele forekommer ham ukendeligt. Han kan ikke engang holde ud at læse, hvad han dengang skrev, hedder det i dagbogen for 5 . december 1805 . Men to omstændigheder sætter ham atter i gang med »oldsagerne« - det ene er hans forelskelse i Constance, det andet er Jens Møllers gendigtning af »Skirners Rejse«. - Han er harmfuld over denne parodi på Edda-digtet, og harmen vækker i ham ønsket. om at blive digter, ja hele Nordens skjald. Tidligere havde han vendt mod Oehlenschläger sagt om de gamle sagaer, at de burde omarbejdes, »ei ordret fordanskes « - nu hedder det omvendt, at de bør gives deres oprindelige form, ikke gendigtes i en ny.

Grundtvig kalder selv den forandring, der er sket med ham i forholdet til det historiske stof for en revidering. Den kronologi, de historiske beretninger har, vil han nu respektere, den historiske fortælling skal ikke længere nøjes med at have sandsynlighedens, men sandhedens mærke.

Men selvom året $\mathrm{r} 8 \mathrm{o} 6$ betyder en afgjort vending, bliver det dog ikke endnu til noget med hans historiske arbejde. Det siges klart i et notat den 24. juni i 807, hvor han fortæller, at han igen har fået en hilsen fra Skougaard med en forespørgsel om, hvordan det går med »oldsagerne«. Grundtvigs reaktion er kort den: »Jeg rødmede ...« - Det gik ikke så godt. Men i samme dagbogsnotat fortæller han, at han har fået at vide, at Nyerup har læst hans indlæg $i \gg N y$ Minerva« om Edda-digtene, og at han har glædet sig over det. Nyerup indvil-

29. »Forsøg til en Oversættelse af Sæmunds Edda« ved B. C. Sandvig i 783 . Saxo Grammaticus »Den danske Krønicke« - udsætt aff Anders Søffrinssøn Vedel I 575. - »Norske Kongers Chronica, « udsat paa Danske af Peder Clausen 1633. Johan Olafsen: »Om Nordens gamle Digtekonst《 1786. Hvitfeld: »Danmarckis Rigis Krønicke« 1652. 
ger nu, sandsynligvis efter tilskyndelse fra Skougaard - også forbindelsen med Nyerup er sikkert Skougaards fortjeneste - i at udlåne bøger og håndskrifter fra universitetbibliotheket til Langeland, en yderst sjælden tjenstvillighed, og brevene til Nyerup (Breve I, I-5) viser, at nu er Grundtvigs forståelse af den videnskabelige metodik i historieforskningen vokset betydelig. Dag for dag arbejder han sig ind i sit stof, han lever mellem Aserne, siger han. Han er på tærskelen til den »galne Tid«, som han kalder $\operatorname{den}^{30}$ ).

Grundtvigs opfattelse af de gamle sagaer og mytologien som et eksistentielt anliggende, en ny livsforklaring og tolkning af tilværelsens inderste gåde har været Skougaard rent ud meningsløst volapyk. Han har set på disse ting med videnskabsmandens kritiske øjne, bundet som han var til oplysningstidens historiesyn og livsopfattelse. Men han har trods alt støttet vennen i det nye reviderede syn ud fra den opfattelse, at intet var bedre til at komme ud af forelskelsens trylleverden end solidt arbejde. På den baggrund må vel også Grundtvigs strålende hyldest til Skougaard i fortalen til »Nordens Mytologi« I8o8 forstås. Skougaard har reddet det menneskelige i ungdomsvennen, tvunget ham til at arbejde positivt og alvorligt, måske ført ham ud af visse suicidale tanker, og formentlig også været den drivende kraft bag Grundtvigs endelige opbrud fra Langeland, lidelsernes ø. I selve fortalen er tonen behersket: »... her greb mig en Vennehaand, som viste mig hen til de vise Oldinge: Snorre og Saxo, i hvis Spor jeg da henvandrede mod Eddas mystiske Skov«. - Men ved den sidste gennemlæsning af fortalen - det haster med at få manuskriptet sendt til bogtrykkeren - har han føjet sin spontane hyldest til Skougaard ind i en fodnote: »Dig, min tidligere Ungdoms eneste Ven, Peder Nikolaj Skougaard! Dig var det, som ledte mig. O! kjendte Flere, som jeg, din stærke Haand, dit dybe og omfattende Blik i Fortid, din næsten overmenneskelige Flid og Udholdenhed, da vilde de bede med mig: at Videnskaben dog ei for stedse maa have mistet sin Yndling!!! «. Men også to andre vidnesbyrd om Grundtvigs taknemmelige følelser over

30. I det utrykte ms. om det antikvariske studium hedder det: »Først da Skougaard, som jeg tænkte var den, der mindst vilde bryde sig om slige Overblik, fra det fjerne (Aalborg) lod mig vide, at han og flere Oldtidens Venner havde frydet sig ved Glimtene, fattede Jeg Mod til at troe, det forsømte endnu lod sig indhente, ved Professor Nyerups Godhed voxde mine Hjelpemidler og med levende Begeistring studerede Jeg $\ll$. - I den trykte afhandling i Dannevirke nævnes Skougaard sammen med Nyerup og Gräter, som en borgen for at Grundtvig ikke »uden Kald« betrådte denne bane. 
for ungdomsvennen findes fra denne tid. Det ene er en optegnelse mellem papirerne fra sommeren 1807 , hvor det hedder, at Skougaard skal have alle hans papirer, hvis han dør. Tanken om en nær forestående død er ham ikke fjern $\mathrm{i}$ disse dage $\mathrm{d}^{31}$ ). - Det andet vidnesbyrd er udkastene fra sommeren 1807 til digtet »Strandbakken ved Egeløkke«, hvoraf fremgår, at Skougaard har aflagt et dramatisk besøg på Langeland - det eneste møde mellem de to venner, vi hører noget om siden studentertiden i København - på et tidspunkt, hvor Constance har været på ferie med sønnen Karl. Der må have været stærke bevæggrunde til dette besøg, som Skougaard aflægger på vej til København, og det er bemærkelsesværdigt, at de ikke følges ad, skønt Grundtvig kort tid efter selv rejser på ferie til Udby. I det stærkt molestrerede manuskript hedder det i Begtrups rekonstruk$\left.\operatorname{tion}^{32}\right)$ )

.. Jeg er vred
Paa Eder, I Dale og Høje,
Paa Eder, I Skove - I veed,
At Han er mig kær som mit Øje,
Som vandrede nys ved min Haand
Hen for Eders Aasyn; I fængsled
Ham ej med uløseligt Baand.
Og Du er mig dobbelt forhadt,
Du Hav med den trillende Vove,
Thi ej Du holdt Tro eller Love,
Bort førte Du Vennen saa brat...
En Ven, ved hvis Tro jeg vil sværge,
En Ven, paa hvis Ord jeg vil dø,
Han er fast som de knejsende Bjerge,
Der krandse hans Fædreneø,
En Ven, ved hvis Side henrunde
I Alderens tidlige Vaar
De sidste, lyksalige Aar.

Til Oldtidens hellige Lunde Jeg fulgte hans stræbende Aand, Han aabned mit lukkede Øje

31. Se Toldberg: »Grundtvig som filolog«, pag. I oo. - Stedet findes fasc. 264, i i Gr.-arkivet. - Se også Toldberg i »Nordisk Tds. for Bok- og Bibliotheksvæsen« I946, pag. I I o ff. - Det suicidale hos Grundtvig skal ingenlunde gøres til mere end det er - det er typisk udtryk for den tids talemåde - se blot C. Molbechs breve og digte.

32. U. S. II, pag 84 . 
Og viste mig Vejen saa nøje

Med Edda og Snorro i Haand.

For favnende Vennen at møde

Han for over Land over Sø

Fra Jotlands det nordlige Øde

Til Lavinds sødtsmilende $\varnothing$.

Saa bort fra de Vange og Skove,

Der fængslede ikke min Ven!

Saa bort fra den trillende Vove,

Som troløs bortførte min Ven! -

Det er en dristig, men ikke usandsynlig tanke, Gustav Albeck fremsætter, når han ud fra disse vers, der ikke blev optaget i den endelige udgave af digtet i »Saga « I8 I 2 - formentlig ikke, som Albeck siger af frygt for censurens vrede, men fordi versene var for personlige til at blive trykt - mener, at det var Skougaards opgave - og fortjeneste - at han fik overtalt Grundtvig til at forlade Langeland og tage til København, glemme sin ulykkelige kærlighed og fordybe sig i arbejdet med $\gg$ Nordens Mytologi $\ll^{33}$ ).

Den sidste mindelse om disse bevægede dage finder vi i digtet »Kjøbenhavn $\ll^{\mathbf{3 4}}$ ), der skildrer det endelig opbrud fra Langeland. Nu går rejsen til den store by, mens Skougaard atter vender tilbage til Aalborg. Med glæde har Grundtvig erfaret, at Trinitatis kirke og den arnemagnæanske samling endnu står trods det engelske bombardement:
Hellige Trefoldighed!
I dit Hus der vil jeg bede
Held til mig i Støvet ned;
Over Huset vil jeg lede ${ }^{35}$ )
Efter dine dunkle Spor
I det stolte, gamle Nord -
Giv da Kløgt og giv da Mod
Til at mane op af Jorden
Ygdrasil med store Rod,
Guderne fra gamle Norden!

33. Se Gustav Albeck: »Strandbakken ved Egeløkke og Havet« i Gr.-studier I 954 og sammes »Grundtvig og Norden«, pag. 23. - Endvidere Rønning I, I, pag. I 9 .

34. P. S. I, nr. 79. Optrykt i »Saga« I 8 I 2.

35. Oven over Trinitatis kirke, hvor den arnemagnæanske samling var. G. Albeck: Omkring Grundtvigs Digtsamlinger, 1955, p. I 12. 
Men gensynet med København er dog ikke særligt tillokkende; der er ingen til at tage imod ham:

\author{
Ingen kjærlig Ungdomsven, \\ Endnu mindre en Veninde. \\ Kun i gamle Pergamenter, \\ Kun i Grublen og i Sang \\ Jeg mig Trøst og Glæde venter; \\ Sukke vil jeg mangen Gang... \\ Ak! naar jeg har sjunget ud, \\ Frels mig da, o hjælp mig, Gud!
}

\title{
IV
}

Dommen over Skougaard vækker betydelig harme hos Grundtvig, men det er bemærkelsesværdigt, at han offentligt er meget varsom med at udtale sig om trykkefrihedsbestemmelserne, mens han derimod privat ikke undlader at sige sin mening klart nok. Det viser sig for eksempel i dagbogsnotaterne for den 31 . december I 804, hvor han gør status over det gamle år. »Mens Jeg imidlertid begyndte og fortsatte flere historiske Fortællinger, glemte Jeg ikke Brevvexel med min fleraarige Ven, nordisk Histories grundige Dyrker, Peder Nikolay Skougaard, hvem en umild Skjebne eller en ubillig Anvendelse af en barbarisk Trykkelov (udhævelsen min) nu synes at ville berøve Dannemark, just i det Øyeblik, Han agtede at vise sit Fædreland, hvad Han kunde blive«. - Dette er skrevet uden offentliggørelse for øje, og viser iøvrigt, at Skougaard også - som nogle år senere Grundtvig selv - har haft tanker om at emigrere. - Ejendommeligt er det i andre af dagbogsoptegnelserne fra 1804 at møde nogle udtalelser af Grundtvig om aristokratiet og præsteskabet. De minder betydeligt om Skougaards voldsomme udfald mod øvrigheden, men er skrevet før Skougaards bog forelå trykt. Grundtvig taler her om, at aristokratiet søger at bilde folket ind, at regeringen er »landsfaderlig«, eller han skriver om den skændige arvefølge, der undertiden lader en uduelig konge følge efter en særdeles duelig. Hans syn på monarkiet er i denne tid oplysningens kongetroskab: det er kongens opgave, når han er duelig, at udvirke »en almindelig Oplysning mellem et Folk, en saadan Oplysning, der lærer Folket at skjønne paa sit eget Vel, at ære den gode Regent, give ham nyttige Vink og befordre hans Pla- 
ner«. En sådan oplysning skulle endvidere hindre, at en uduelig konge (Grundtvigs udtalelser er i følge Begtrup blevet til efter læsning af en bog om Frederik den Tredje - hvilken siges ikke) efterfølger en duelig monark, eller udvirke at en sådan afsættes. Det hedder i Grundtvigs overvejelser, at ubegrænset frihed dog er umulig i en stat, da den i så fald ville ophøre med at være en stat. Fuldkommen lighed er en »Sjimære«. I stedet hævder Grundtvig, at den enkelte skal have frihed til »at benytte sine Evner uden at giøre Indgreb i andres fuldkomne Rettigheder «. Ingen skal ved protektion kunne opnå noget som helst $\mathrm{i}$ staten, men kun ved »sine høiere Sjels Fortrin«. Kun sådanne aristokrater skulle være til $\_^{36}$ ).

I afhandlingen »Om Videnskabelighed og dens Fremme fra »Ny Minerva 1807 vender Grundtvig tilbage til emnet og udtrykker sig tilsvarende forsigtig, men ikke uden en vis Åbenhed: »Jeg veed ikke rettere, end at alle ældre Trykkelove ere ophævede ved Forordningen af 2 Ide Sept. I 799, og uagtet nogle Punkter i samme maaskee taale en, for Videnskaberne mindre gunstig Tydning, troer jeg dog ikke, de vilde finde sig synderlig trykkede af den, især dersom det ved et Kongebud indskiærpedes Dommeren at holde sig nøie til den, uden nogen Anvendelse af ældre Love, og naar videnskabelig Anonymitet tillodes«. - Det er tydeligt, at Grundtvigs irritation skyldes, at Skougaard er blevet dømt ikke efter forordningen alene, men efter det såkaldte Kirkeritual fra $\mathrm{i} 685$, der ikke burde finde anvendelse $\mathrm{i}$ en sådan sag, hvilket må siges at være rigtigt; samt at videnskabelige værker ikke måtte udgives pseudonymt. - $\mathrm{Og} \mathrm{i}$ en fodnote retter han et spørgsmål til Danmarks jurister: »Her være det mig tilladt at giøre et Spørgsmaal til Danmarks Lovkyndige: hvorvidt kan en Forfatter, efter giældende Love for Trykkefriheden, ansees strafskyldig ved at dadle en afdød dansk Konge? Spørgsmålet er ikke uvigtigt for Nordens Historie, og sikkert var det at ønske, vi herom havde en nøiag-

36. Notaterne er fra april I804, den senere omtalte recension af Bornholmsbeskrivelsen er fra 4.-I I. oktober. Muligheden for at Grundtvig kan have læst Skougaards bog i manuskript eller før den offentligt udkom, kan vel ikke afvises helt.

37. En undersøgelse af Grundtvigs forhold til censuren må samle sig om en artikel i Skilderiet af 15. september I 8 I 2, hvor han forsvarer censur, 》Mit litteraire Testamente《 1826 , digtet til kongen: 》Taksigelsen« i P.S. V, nr. 68, »Om Religionsfrihed « I I 1827 , Politiske Betragtninger « I 83 I, 》Det danske Fiirkløver « 1836 , brevet til censor Reiersen 27. aug. 1837, 》Udkast til en ny Trykkelov《 I 845 og »Danskeren《 I 849. Se Steen Johansen: »Fund og Forskning IV, 1957, Poul Andersen: »Grundtvig som Rigsdagsmand« 1940, $22 \mathrm{ff}$. 
tig Bestemmelse, hvorved Historieskriveren sikredes for, imod sin Villie at paadrage sig Tiltale«. - Mange år senere beskæftiger Grundtvig sig igen med det samme problem - det har ligget i hans sind og er vågnet ved hans egen domfældelse efter samme forordnings $\S$ i 2 og Danske Lov. Det er i I. del af »Om Religionsfrihed«, der var blevet trykt og forsynet med censors tilladelse: »Maa trykkes« - da censor alligevel forbød det efter kancelliets henstilling. Man havde regnet med tilladelsen på forhånd. Først 1866 blev afhandlingen frigivet. Det hedder i denne sidste del af Grundtvigs skrift: »At det saaledes langt mere er Raissonnementet paa fri Haand over hvad der i hvert enkelt Tilfælde skal kjendes for Ret, langt mere det, end Trykkeforordningen, der gjør Skribent-Vejen aldeles usikker, kan jeg ikke bedre oplyse, end ved at sammenligne to Skribenters forunderlige Skæbne ved samme Ret, min egen nemlig, og en af mine Ungdoms-Venners. Det var nemlig 1804, at en et og tyve Aars Yngling, tidlig historisk-lærd, midt $i$ et strængt videnskabeligt Arbeide, sagde nogle usømmelige Ord om en af vore længst hensovne Konger, men derom talde TrykkeForordningen ikke, og det er klart, at ingen Lov kan befatte sig med Sligt, uden at tilintetgjøre den historiske Frihed, hvis Brug er Staten saa vigtig, og hvis Misbrug er den saa uskadelig, at den sikkert bør haandhæves. Mueligt, at der i dette Tilfælde var Noget som kunde fordre en Undtagelse, men hvad jeg vilde sige, er, at man kaldte $\mathrm{Ri}$ tualet til Hjelp, som forbyder (præsterne) at tale ilde om de Døde i deres Liig-Prædiken, og det er klart, at kunde Sligt medvirke det Mindste til, at en ung Historiker kom til at sidde paa Vand og Brød, hvad han rigtignok, under sit utrættelige Studium var vant til, men ikke som Misdæder, og at han gik tabt for Videnskaberne, hvilken levende Skribent kunde da ikke falde, før han vidste det!« I samme afsnit taler Grundtvig med harme om sin egen dom: »... den skal være fældet udelukkende efter en enkelt Forordning «. Men dette er ikke rigtigt, idet han også blev dømt ifølge Danske Lov § 6.2 I.4. Dernæst hedder det, at han og de andre censurdømte blev underkastet denne censur ifølge »de hemmelige Rets-Principper« men dette er heller ikke rigtigt, idet forordningens § 20 klart siger: »Ingen maa, efter at han ved Dom er blevet kjendt skyldig i Overtrædelse af denne Forordning lade noget Skrift trykke, forinden Manuskriptet er blevet forevist Stedets Politimester og af ham paategnet, at det maa trykkes«. Forordningens bestemmelse om automatisk og livsvarig censur af forfattere, der er dømt, ophævedes først. I 837. Grundtvig kalder så iøv- 
rigt sin dom for »ingen Dom efter Trykke-Forordningen, men over den ...«

Grundtvigs forhold til censur-spørgsmålet og censurens betydning for hans litterære produktion er et problem, som ikke skal behandles her. Kun antydninger må nævnes: Grundtvig var hele sin tid kongetro - og i den her behandlede periode tilhænger af enevælden. Hans syn på trykkefrihedsloven er bestemt heraf, selvom han i dagbogsoptegnelsen fra 31 . december 1804 kalder den barbarisk. Udadtil var han tilhænger af loven, omend han peger på, at lovens udøvere nok kunne vise mere smidighed og tage større hensyn til skribenter. Som vi har set $\mathrm{i}$ afhandlingen $\gg \mathrm{Om}$ Religionsfrihed«, vil han ikke benægte, at der kunne have været grunde for regeringen til at gribe ind over for visse udtalelser i Skougaards Bornholms-beskrivelse 1804, men han synes, som naturligt var, at straffen var urimelig hård i forhold til forseelserne. Det væsentligste her er at forstå den forskel, der er på Grundtvigs og Skougaards reaktion på den dom, der ramte dem begge og den medfølgende censur, der blev hævet for Grundtvig I 838, efter hans egen ansøgning, men varede ved hele livet for Skougaards vedkommende. Dommen slog tilsyneladende Skougaard ud, men satte Grundtvig i større virksomhed og øgede hans produktion og bestemte den i positiv retning. Heri ses også en afgørende forskel i de to venners natur.

\section{$\mathrm{V}$}

Mellem Grundtvigs dagbogsblade fra den 4.-I I. oktober I804, sandsynligvis skrevet i Udby, hvor han opholder sig efter overstået embedseksamen, findes nogle optegnelser om Skougaards samme år udkomne bog -: »Et Par Ord om og af første Delen af Skougaards Bornholms Beskrivelse $\left.\ll^{38}\right)$. - De viser, at bogen også har interesseret Grundtvig, skønt emnet vel ellers, såvel som øen, måtte forekomme ham noget fjerntliggende. - Der indledes med nogle ord om selve sproget i Skougaards værk: »Ortografien er saare god - efter mine Tanker - skjønt ey allevegne overensstemmende med mine Begreber ... Substantivernes Pluraler ere saare underlige, men da Han selv har vedrørt dem i Fortalen, forbigaaer jeg dem ...«-Skougaard forsøger i sin bog at indføre den bornholmske grammatik i rigssproget, hvilket også kritiseres af Thaarup i nævnte utrykte recension:

38. Afskriften af ms. er foretaget af professor, dr. phil. Gustav Albeck og cand. mag. J. K. Jensen, hvem jeg bringer en hjertelig tak. 
»Dersom Forfatteren vil (som man synes) have den Bornholmske Dialekt anseet som et særskilt Sprog, saa burde han enten have skrevet reen Bornholmsk eller reen Dansk, og ikke, som nu, et Sprog der er ingen af Delene«. - Derefter beskæftiger Grundtvig sig en del med oprindelsen til navnet Bornholm. Det hedder: $\gg$ Fra I til 4 tales om Oprindelsen til Bornholms Navn, og bortkaster Sk. med Rette Niels Pedersens Digt ${ }^{39}$ ), men ingen Grund seer jeg hvi Han antager Torfesens ${ }^{40}$ ) som bedre ... Sk.'s egen Hypothes maa for sin Simpelheds Skyld vinde Alles Bifald som rimelig, thi paa Vished kan ved slige Ting ey være at tænke ...«Videre hævder Grundtvig, at Skougaard bedre end de Thura ${ }^{41}$ ) har truffet Knytlingesagaens mening om navnets oprindelse. I sin bog omtaler Skougaard indgående »Niels Pedersens Digt« - der i sin bog: »Cimbrers oc Gothers ældgamle Herkomst oc Handel« giver en forklaring, der igen støttes af Strelov i hans »Guthilandiske Chronica « fra $1633^{42}$. Det siges her, at navnet stammer fra en Cimbrer, der hed Beor eller Breor, som året 2264 efter verdens skabelse - når det så end er - rejste fra Sverrig til den ukendte $ø$, tog den i besiddelse og befolkede den, hvorved den fik navnet Beorsholm. Også de Thura slutter sig til denne tydning. Hos Torfesen finder vi en anden tydning. Han skriver, at det var en kvinde ved navn Burgund, der gav øen navn. Skougaard siger i sin beskrivelse, at han vælger Torfesens tydning som den mest sandsynlige, samtidig med at han giver sin egen - langt sandsynligere - forklaring på navnet: Oprindeligt hed den kun Holm, øen, latin hulmus, men da man byggede adskillige borge rundt om på den for at holde sig fjenderne fra livet, blev navnet efterhånden til Borg-holm.

Senere i sin recension over Skougaards bog anker Grundtvig over, at der tales nedsættende om Thorgild Fjeldsted ( I 778- I 784 amtmand

39. Niels Pedersen (Nicolaus Petræjus) historiker og præst på Gulland, Visby. Den såkaldte »gullandske hypotese« vækker megen forvirring på grund af sin fantasifuldhed. Grundtvigs afvisning af den er helt rimelig.

40. Tormodæus Torfæus ( I639-I 7 I9) islandsk forfatter, oversætter islandske sagn til Frederik den Tredje, bringer adskillige håndskrifter, bl. a. Eddaerne til Danmark og skænker dem til kongen. Udgiver I 7 I I: 》Historia rerum Norvegiacarum $\ll$.

41. Laurids de Thura udgav i 756 den første trykte beskrivelse af Bornholm. Hans hjemmelsmand var amtmand Urne. Fr. Thaarup påstår, med urette, i sin utrykte recension, at Skougaard havde skrevet hele »lange Akter « af efter de Thura og andre ældre skrifter.

42. Hans Nielsen Strelov, f. i Visby 1587, præst, provst og superintendent Gotland, død ${ }_{1} 656$. 
på Bornholm), hvis Skrift Promemoria ofte citeres af Skougaard. Fjeldsted anker over tiltagende hjemmebrænderi, men Grundtvig siger hertil, at Skougaard er med til at »kaste Skygge paa en Mands Karakter, der almindelig er bekjendt for en brav og indsigtsfuld Mand, og derfor ønskede Jeg min gode Ven ey ved en Henpegen havde ladet tilsyne, Han troede Fjeldsted havde sværtet Bornholmerne, fordi de ey i Alt vilde lystre ham. Man bør ey give noget Vink om uædle Grunde - dem Ingen kan kjende - hos en ædel Mand «.

I sine notater for oktober måned omtaler Grundtvig i gennemgangen af Bornholms beskrivelsen en plan om ansættelse af vandrelærere på Bornholm, fremsat af præsten Elieser Gad i Pedersker, senere $\left.R \theta^{43}\right)$. Gad skriver en pjece 1803 om $\gg$ Den nuværende Tilstand af Undervisningsanstalterne og deres mulige Forbedring $\ll$, og det lille skrift vækker en sådan harme, især hos hans kollega, præsten i Aaker, Peder Thomsen Balle, at han måtte forlade øen. Gad døde som præst ved Roskilde domkirke. I sin bog forsvarer Skougaard Gad og siger at der var »adskilligt ganske rigtigt og godt i Hr. Gads Plan«. Grundtvig synes at have sat sig en del ind i denne bornholmske strid om skolevæsenet, og hævder, at Skougaard er partisk i striden, når han er stærkt imod tanken om vandrelærere: »Af dette her anførte troer Jeg mig berettiget til at gjøre slig Slutning: at den omvandrende Lærer, saaledes som Gad foreslaaer ham, vilde blive et meget skadende Menneske i sit Distrikt, hvor han egentlig ey kunde være eller ansees for at være andet, end en privilegeret Betler, den Bønderne havde at føde ...«-Grundtvig indvender over for disse ord af Skougaard meget fornuftigt, at hvis Bornholmerne virkelig var interesserede i skolesagen, ville de næppe anse en vandrelærer for en tigger, dersom han underviser deres børn godt og grundigt, og dersom vandrelærerne blev omkringstrejfende tiggere, vilde grunden simpelthen være den, at man »antog uduelige og slet moralske Mennesker«, hvilket man ikke på forhånd kunne mene, de ville gøre.

Senere omtaler Skougaard under beskrivelsen af Knudsker sogn, hans fødeegn, de gamle tingsten og giver en skarp, ironisk omtale af det, han kalder »de forrige, gyldne, demokratiske Tider « - den tid, hvor bønderne var fri mænd, der »mødte paa Tinge for enten at samtykke eller forkaste de Stores: Kongernes og deres Befalingsmænd, Beslutninger Landet angaaende ...« Dette får Grundtvig til at rette

43. K. E. Bugge siger $\mathrm{i}$ sin disputats (pag. 66), at Grundtvig næppe fik nogen pædagogiske impulser fra Skougaard, hvad sikkert er rigtigt. 
en besk kritik mod Skougaards sarkastiske udtryksmåde: 》3 I 7-I 7-I 9 er mærkelig dels for Materiens Skyld, dels fordi det er Bogens eneste deklamatoriske Sted som tillige viser Forfatterens politiske Tænkemåde $\left.\ll^{44}\right)$.

Skougaard slutter dette afsnit med følgende ord: »Dog, hvad hjælper det at tale om hine svundne Odelskabs og Folkefriheds Dage, før Præstemagtens, det plattydske Aristokraties og Lensmændenes Tid her i Danmark « - Ikke underligt, at myndighederne måtte reagere over for en så udfordrende tone, om end der er mere ironi end egentlig udfordring. - Man forstod ikke det særegne i Skougaards måde at skrive på - den blanding af det revolutionære, det »deklamatoriske og det sarkastiske, underfundigt ironiske, som kendetegner hans stil. Denne skjulte humor og åbenbare ironi var et særkende for Skougaard og er ikke bornholmere fremmed. Grundtvig har vel til en vis grad forstået denne humor - særlig et sted, hvor han citerer Skougaard, da han beskriver sine følelser ved en tur i Ringe bakker i Knudsker. Her kommer hans kærlighed til fødeøen stærkt frem samtidig med, at han måske også røber et vist fremsyn, som var sjældent. Han forudser, at man i kommende år vil finde vej til Bornholm, mens turistrejserne ellers går til Schweitz. Det er bemærkelsesværdigt, at Skougaard i sin Bornholms-Beskrivelse fra I804 skriver om turismen og de dermed forbundne økonomiske problemer. - Grundtvig gengiver en hel del af dette afsnit hos ham, åbenbart også fordi han finder en god portion selvglad lokalpatriotisme i betragtningerne. - Skougaard peger i det følgende på, at Bornholm har adskilligt, som Schweitz ikke har: udsigten til havet med engelske handelsskibe og russiske krigsfartøjer (det er som om denne skildring er blevet til i et senere århundrede), og fordelene ved at berejse Schweitz, hvor der ikke tales dansk, er næppe større end ved at lægge sine turistrejser til Bornholm, hvor der ganske vist heller ikke tales dansk. - men ved at rejse dertil, opnår man dog, siger han, at lægge pengene i landet og ikke bruge fremmed valuta ${ }^{45}$ ). - Grundtvig kommenterer dette afsnit af Skougaards bog med ordene: »Ja, snak du for din Æssk.« Han siger, i en let ironiserende tone, at det måske er forfatterens hensigt at bevirke, at pengene bliver brugt i landet fremfor at ødsles på

44. Hos Fr. Thaarup hedder det om stedet (i den utrykte recension): »... charakteriserer ret Forfatterens saavelsom den almindelige Mands Tænkemaade paa Bornholm «.

45. Den første egentlige turistbeskrivelse af Bornholm kommer I819 med Rawert og Garliebs skildring af en rejse i 8 i 5 . 
udenlandsrejser. »Ja, hvem veed om Han ikke har i Sinde at nedsætte sig som Gjæstgiver ved Ringe Klipperne eller et andet Sted derovre. Man skulde snart tro det siden han prokurerer saa ivrigt«.

Under omtalen af Olsker sogn og Hammershus ruiner kommer Skougaard ind på spørgsmålet om Corfits Ulfeldt og hans forhold til kongen - det afsnit, der i særlig grad blev fældende for ham som historisk forfatter. Grundtvig citerer et godt stykke af dette. Skougaard skriver om skamstøtten for Ulfeldt, der står til evig skændsel, men ikke for Ulfeldt, derimod for kongen og hans hofkryb. Sympatien er i denne bog ganske på Ulfeldts side, hvorimod han i »Bornholms Saga« 1834 ikke levner Ulfeldt ret megen ære - kalder ham en ussel landsforrædder. I8o4 hedder det om ham, at han er »denne store, sin Tids største Mand«. I »Sagaen« skriver han: »Korfits Ulfeld, en Mand med store Rigdomme, store Talenter, stor Slægt, havde de mægtigste Aristokrater paa sin Side, og Kongens Haandfæstning havde gjort Kongemagten til næsten Intet, men Ulfelds umættelige Ærgjerrighed, hans Herskesyge paadrog ham mange af de Stores Fiendskab, ligesom hans Magt, der overskred alle rimelige Grænser, skabte ham Misundere og Efterstræbere i stor Mængde . . .« - I Bornholms-Beskrivelsen 1804 er Ulfeldt en anderledes stor skikkelse, der lider blodig uret: »Dog naar havde Danmark ogsaa en stor Mand, der ey maatte lide Uret Mon dette har været Tilfældet nogensinde fra Tyge Brahes Dage til de senere Tider « - Skougaard, af hvem Grundtvig netop citerer en hel del om dette emne, vil dog ikke gå nærmere ind på spørgsmålet, da det er en beskrivelse af øen, han vil give, »og ey en Efterretning om de Fornemmes Skurkestreger og Hofkabaler i Dronning Sofie Amalies Tid, som fordres her«. - Grundtvig er nu ikke så sikker på Skougaards bedømmelse i den sag: »At (Ulfel) Uhlefeld skedte megen Uret derom kan neppe være nogen Tvivl, men om Han var, eller vilde som Formaaende (?) blevet en virkelig nyttig Mand for sit Fædreland hvilket den store Mand absolut maa være naar Han staar paa en Post der aabner vid Virksomhedskreds er et Spørgsmaal der hører Dristighed til at besvare med Ja, thi at Jeg ikke skal tale om Uhlefelds Stolthed og Ærgjerrighed der saare let kunde komme i Kollisjon med Landets Vel, saa synes Landets Tilstand i fjerde Kristians sidste Aar da Uhlefeld - som Adelens Hoved og Kongens Svigersøn - formaaede saa saare meget, ikke at afgive noget hæderligt Bevis paa hans Storhed «.

Beskrivelsen over Bornholm slutter med en bornholmsk ordbog, og 
hertil har Grundtvig også en række bemærkninger, der dog ikke er fuldendt. Der er en lakune i dagbogen. Men dette falder uden for vort emne.

Det er tydeligt, at Grundtvig med forventning og begærlighed har grebet Skougaards Bornholms beskrivelse - det var jo vennens første historiske værk, og Grundtvig synes at have gjort sig store anstrengelser for såvel at forstå det specielle emne, Bornholms historie, som Skougaards særlige humor. Men han er ingenlunde ukritisk over for vennens bog. Især må han som det kongetro og autoritetsbundne menneske han var gå i rette med Skougaards respektløse udtalelser om kong Frederik den Tredje og øens militære såvelsom civile mydigheder. På den anden side er det dog vist givet, at Grundtvig ikke er blevet helt upåvirket af Skougaards kamp for den personlige frihed i modsætning til den oplyste enevældes autoritetsdyrkelse.

Og endelig viser Grundtvigs notater vedrørende Skougaards ufuldendte og ufuldstændige bornholmske ordbog, at han begynder at interessere sig for noget andet end det strengt historiske, nemlig filo$\left.\operatorname{logien}^{46}\right)$.

\section{VI}

At tegne et billede af mennesket P. N. Skougaard på baggrund af det ret sparsomme materiale, vi har til rådighed, er ingenlunde let, men enkelte træk synes dog at stå skarpe. Han har været en sproglig begavelse, der tidligt beherskede det islandske og var fortrolig med runeskrifterne, og som translatør mestrede han tysk, engelsk, spansk, hollandsk og svensk. Hans anlæg for mathematikken kan ikke efterprøves, men det er vel karakteristisk for ham, at hans forkærlighed for denne videnskab skyldes mathematikkens aprioriske væsen, dens klare logik. Som historieforsker var han præget af oplysningstidens objektive syn på de historiske begivenheder ${ }^{47}$ ). Romantik, det åndshistoriske eller som Grundtvig senere kaldte det: det historisk-poetiske har ligget Skougaard umådeligt fjernt og filosofisk som religiøst hørte han til oplysningstidens fornufttilbedere. Når Grundtvig, der ellers ikke beundrede andre mennesker, men tit lod dem mærke sin bidende spot, om Skougaard kan sige, at aldrig har han beundret no-

46. Se Toldberg: »Grundtvig som filolog «, pag. 55 .

47. Michelsen gør i sin disputats regnskabet op således: Bruuns »Skriftemaalet《 vækker Grundtvigs harme, Fr. Sneedorf hans interesse for selve historien, Suhm sætter hans fantasi igang, og Skougaard fører denne historiske sans ind på sin rette videnskabelige bane. 
get menneske som han, skyldes det formentlig Skougaards overlegenhed, hvad flid og umættelig forskertrang angår, men også den personlige hjælp Skougaard yder ham dels ved at udvælge den litteratur, han skulle ty til, og dels den menneskelige hjælp, Skougaard har ydet ham i den krise, der truer hans liv efter mødet med Constance på Egeløkke. Taknemmeligheden, der strømmer over alle bredder i fodnoten i fortalen til »Nordens Mytologi«, er vel et udtryk for, at. Skougaard næsten bogstaveligt har reddet Grundtvigs liv.

Begge har været enspændernaturer og begge kalder hinanden for deres ungdoms eneste ven. Skougaard dækkede sit sårbare sind bag den skarpe ironi og ætsende sarkasme, der af omgivelserne måtte forstås som arrogance. Det siges med rette $\mathrm{i}$ nekrologen over ham i hans gamle blad, at ingen mestrede ironiens kunst som han - det kunne tilføjes, at ingen betalte så høj en pris for dette mesterskab som Skougaard. Hvad forholdet mellem Grundtvig og Skougaard iøvrigt angår, er det vel værd at mærke sig, at mens Grundtvig altid lader sig udfordre af ydre modgang til stadig større ydelser, vender Skougaard sig indad, trækker sig tilbage $\mathrm{i}$ et sneglehus af bitterhed og skuffelse. I sine ansøgninger til kancelliet om fritagelse for retsforfølgelse og straf røber han, at der har været træk af paranoia i hans natur. Han føler sig omgivet af lutter fjendtligtsindede og udeltagende mennesker. Bag hans skarpe ironi lå en veghed i sindet, en selvkredsen om den uret, han følte sig ramt af, om den mangel på anerkendelse, der formørkede hans liv. Man har her givet den livsvarige censur skylden, men nok for en del med urette. Trods censur og straf fik han dog kongelig anerkendelse som translatør i Aalborg, og levede en række år tilsyneladende solende sig i popularitet og selskabelighed. Årsagen til hans noget tragiske liv lå ikke blot i ydre, men også $\mathrm{i}$ indre forhold. For en videnskabelige interesseret og begavet mand som Skougaard var det $\mathrm{i}$ hine tider en forvisning at skulle bo i det »mercantile« Aalborg. Han var fuldstændig afskåret fra at dyrke de videnskabsgrene, der havde hans brændende interesse, og som han både kundskabsmæssig og intellektuelt var rustet til at gå i lag med. Mangelen på videnskabeligt materiale og hjælpemidler var måske en hårdere kondition end censuren. $\mathrm{Og}$ dog tyder meget på, at årsagen til hans senere elendighed var af personlig karakter. Nok var han ensom og i Aalborg-tiden sat til mange ting, der ikke lå for ham - undervisning af børn, mæglervirksomhed med ærinder for svenske skippere, salg af kaffe, translatør-arbejde med ligegyldige aktstykker 
- men endte hans liv tragisk, lå betingelserne $\mathrm{i}$ hans væsens forgjorthed. Han var en af dem, der uvilkårligt måtte blive draget mod tragedien.

Mødet med Skougaard fik altså afgørende betydning for den unge Grundtvig, der flere gange omtaler mødet med ham på en sådan måde, at der lå noget skæbnebestemt deri. »Det efter talemåden tilfældige bekendtskab «, kalder han forholdet til Skougaard. Det er vanskeligt at se, hvordan Grundtvig ville være blevet den, han blev, uden Skougaards indflydelse. Havde denne ikke hold i sig selv, havde han det åbenbart i Grundtvig, og det må være Skougaards fortjeneste, at han vakte Grundtvigs interesse for historien og mytologien, tvang ham til at lære Islandsk, udvalgte for ham de bøger, han skulle læse på Egeløkke, opmuntrede ham i den kritiske tid med forelskelsen i Constance til at arbejde sig ud af krisen, knyttede forbindelsen med Nyerup og åbnede den arnemagnæanske samlings guldgruber for ham.

Peter Nikolaj Skougaard fortjener oprejsning for den uret samtidens historikere gjorde ham efter hans død - og for den forholdsvis ringe omtale, han i Grundtvig-litteraturen har været genstand for. 